\title{
Novel Platinum-Porphyrin as Sensing Compound for Efficient Fluorescent and Electrochemical Detection of $\mathrm{H}_{2} \mathrm{O}_{2}$
}

\author{
Eugenia Fagadar-Cosma ${ }^{1} * \mathbb{C}$, Nicoleta Plesu ${ }^{1}$, Anca Lascu ${ }^{1}$, Diana Anghel ${ }^{1}$, Maria Cazacu ${ }^{2} \mathbb{D}$, \\ Catalin Ianasi ${ }^{1}$ (D), Gheorghe Fagadar-Cosma ${ }^{3}$, Ion Fratilescu ${ }^{1}$ and Camelia Epuran ${ }^{1}$ \\ 1 "Coriolan Dragulescu" Institute of Chemistry of Romanian Academy, Mihai Viteazu Ave., No. 24, \\ 300223 Timisoara, Romania; nplesu@acad-icht.tm.edu.ro (N.P.); alascu@acad-icht.tm.edu.ro (A.L.); \\ danghel@acad-icht.tm.edu.ro (D.A.); ianasic@acad-icht.tm.edu.ro (C.I.); \\ ionfratilescu@acad-icht.tm.edu.ro (I.F.); ecamelia@acad-icht.tm.edu.ro (C.E.) \\ 2 Institute of Macromolecular Chemistry "Petru Poni”, Grigore Ghica Vodă Alley, No. 41A, 700487 Iasi, \\ Romania; mcazacu@icmpp.ro \\ 3 Faculty of Industrial Chemistry and Environmental Engineering, Politehnica University of Timisoara, \\ Vasile Pârvan Ave., No. 6, RO 300223 Timisoara, Romania; gheorghe.fagadar@upt.ro \\ * Correspondence: efagadar@yahoo.com or efagadarcosma@acad-icht.tm.edu.ro; Tel.: +40-256-491-818
}

Received: 18 March 2020; Accepted: 21 April 2020; Published: 23 April 2020

\begin{abstract}
Metalloporphyrins are highly recognized for their capacity to act as sensitive substances used in formulation of optical, fluorescent, and electrochemical sensors. A novel compound, namely $\mathrm{Pt}(\mathrm{II})-5,10,15,20$-tetra-(4-allyloxy-phenyl) porphyrin, was synthesized by metalation with $\mathrm{PtCl}_{2}(\mathrm{PhCN})_{2}$ of the corresponding porphyrin base and was fully characterized by UV-vis, fluorimetry, FT-IR, ${ }^{1} \mathrm{H}-\mathrm{NMR}$, and ${ }^{13} \mathrm{C}-\mathrm{NMR}$ methods. The fluorescence response of this Pt-porphyrin in the presence of different concentrations of hydrogen peroxide was investigated. Besides, modified glassy carbon electrodes with this Pt-porphyrin (Pt-Porf-GCE) were realized and several electrochemical characterizations were comparatively performed with bare glassy carbon electrodes (GCE), in the absence or presence of hydrogen peroxide. The Pt-porphyrin demonstrated to be a successful sensitive material for the detection of hydrogen peroxide both by fluorimetric method in a concentration range relevant for biological samples $\left(1.05-3.9 \times 10^{-7} \mathrm{M}\right)$ and by electrochemical method, in a larger concentration range from $1 \times 10^{-6} \mathrm{M}$ to $5 \times 10^{-5} \mathrm{M}$. Based on different methods, this Pt-porphyrin can cover detection in diverse fields, from medical tests to food and agricultural monitoring, proving high accuracy (correlation coefficients over 99\%) in both fluorimetric and electrochemical measurements.
\end{abstract}

Keywords: Pt-porphyrin; photoactive material; UV-vis spectroscopy; fluorimetry; electrochemistry; hydrogen peroxide detection

\section{Introduction}

The detection and quantification of oxygen in its various forms is of great importance because reactive oxygen species (ROS), such as: peroxide radicals $\left(\mathrm{ROO}^{\bullet}\right)$, hydroxyl radical $\left({ }^{\bullet} \mathrm{OH}\right)$, hydrogen peroxide $\left(\mathrm{H}_{2} \mathrm{O}_{2}\right)$, singlet oxygen $\left({ }^{1} \mathrm{O}_{2}\right)$, and ozone $\left(\mathrm{O}_{3}\right)$ are intracellularly generated during some of the enzymatic oxidation processes that are involved in the metabolism of proteins, carbohydrates and fats [1]. The normal concentrations of $\mathrm{H}_{2} \mathrm{O}_{2}$ for plasma were determined to be $1-5 \mu \mathrm{M}$, while higher values, in the range of 30-50 $\mu \mathrm{M}$, can appear during chronic inflammation [2]. In the urine of healthy subjects, the creatinine-corrected $\mathrm{H}_{2} \mathrm{O}_{2}$ concentration varies in the range 276-1844 $\mu \mathrm{M}$, regardless of gender [3]. Reduced oxygen levels are developed in cardiac and brain ischemia [4]. Moreover, $\mathrm{H}_{2} \mathrm{O}_{2}$ present in blood can interact with $\mathrm{Fe}^{2+}$ ions contributing to oxidative stress [5]. 
Quantifying the dissolved $\mathrm{O}_{2}$ in water was realized using a three-dimensional matrix, containing platinum-tetraphenylporphyrin bonded with 3-(trimethoxysilyl)-propyl-methacrylate on the surface of polydimethylsiloxane with a detection limit of $4.7 \mu \mathrm{M}$ [6]. The detection is based on the reversible fluorescence response of the Pt-porphyrin to different concentrations of dissolved $\mathrm{O}_{2}$ in water. Based on the same method, other platinum fluorescent compound, $\mathrm{Pt}$ (II)-5-(3-aminophenyl)-10,15,20-tris-( $p$-tolyl)-porphyrin, incorporated in polyimide polymers was capable of detecting oxygen in concentrations up to $10 \%$ [7].

Composite strips comprising Pt(II)-meso-tetrakis-(pentafluorophenyl)-porphyrin and cadmium telluride quantum dots were used for rapid colorimetric determination [8,9] of oxygen. High fluorescence quantum yield hybrid materials based on phenylacetylide fibers functionalized with platinum (II) meso-tetraphenylporphyrins were developed and showed improved sensitivity to $\mathrm{O}_{2}$, providing a detection limit of $7.5 \mathrm{ppm}$. The response to oxygen detection was significantly improved by adding silver nanoparticles to the hybrid material [9]. A recent work [10] showed that $\mathrm{Pt}$ (II)-complex with octaethylporphyrin-ketone is a near-infrared spectroscopy (NIR) emitting oxygen indicator.

Pt-porphyrins have been used extensively in polymeric membranes to detect molecular oxygen, but because of their small tendency to bind axial ligands [11,12] they have not been largely investigated as ionophores [13]. Potentiometric studies of Pt-porphyrins as ionophores became significant only after platinum-tetraphenylporphyrinates-based polymeric film sensors were successfully applied for analysis of wines [14]. Few years later, electrodes prepared with membrane containing $\mathrm{Pt}(\mathrm{II})$-tetraphenylporphyrin responded to iodide with the Nernstian slope of $58.8 \mathrm{mV}$ per decade, in $10^{-5}$ to $10^{-2} \mathrm{M}$ iodide activity range. The same study revealed that $\mathrm{Pt}(\mathrm{II})$-octaethylporphyrin exhibits enhanced selectivity for iodide-ion recognition than $\mathrm{Pt}(\mathrm{II})$-tetraphenylporphyrin [15].

In the last decade, our team demonstrated expertise in optical [16], fluorescent $[17,18]$ and electrochemical $[19,20]$ detection of minute concentrations of hydrogen peroxide, in a range that is highly relevant for medical tests, using as sensitive materials $\mathrm{Mn}$ (III)- and $\mathrm{Co}(\mathrm{II})$-metalloporphyrinates. Our next approach was to synthesize and test the sensitivity toward $\mathrm{H}_{2} \mathrm{O}_{2}$ of other metalloporphyrin structures, especially Pt-derivatives, for improving selectivity, sensitivity, and the detection concentration domain, preserving high accuracy.

The main purpose of this work was to synthesize a novel fluorescent Pt-metalloporphyrin with the capability of recognizing and monitoring ROS species, especially $\mathrm{H}_{2} \mathrm{O}_{2}$. We expected that an allyloxy substituted porphyrin would be more sensitive, due to both electron-withdrawing effect of allyloxy group and the expected electromeric effect caused during the interaction with an analyte. Besides, the flexible peripheral allyloxy groups might prevent fast aggregation and, in this case, the fast quenching of fluorescence.

\section{Materials and Methods}

\subsection{Chemicals}

The used solvents were hexane $\left(\mathrm{C}_{6} \mathrm{H}_{14}\right)$, chlorobenzene $\left(\mathrm{C}_{6} \mathrm{H}_{5} \mathrm{Cl}\right)$, tetrahydrofuran (THF), chloroform $\left(\mathrm{CHCl}_{3}\right)$, dichloromethane $\left(\mathrm{CH}_{2} \mathrm{Cl}_{2}\right)$, benzonitrile $\left(\mathrm{C}_{6} \mathrm{H}_{5} \mathrm{CN}\right), \mathrm{N}, \mathrm{N}$-dimethylformamide (DMF), and dimethylsulfoxide (DMSO), purchased from Merck (Darmstadt, Germany), Sigma-Aldrich (St. Louis, MO, USA) and all were used as received. Double distilled water was used in all experiments. All chemicals used in synthesis of free 5,10,15,20-tetra-(4-allyloxy-phenyl)-porphyrin were p.a. grade and were purchased from Merck (Darmstadt, Germany) and used as received, except for pyrrole that was distilled prior to use. The platinum water soluble complex $\mathrm{PtCl}_{2}(\mathrm{PhCN})_{2}$ was provided by Alfa (Haverhill, MA, USA).

\subsection{Apparatus}

UV-visible spectra were performed using $1 \mathrm{~cm}$ wide quartz cuvettes, on a JASCO UV-visible spectrometer, V-650 model (Pfungstadt, Germany). The emission spectra were recorded in DMSO-water 
system, on a Perkin Elmer LS55 luminescence spectrometer (Perkin Elmer, Inc./UK Model/LS 55, Waltham, MA, USA). Fluorescence spectra were recorded at ambient temperature $\left(22-24{ }^{\circ} \mathrm{C}\right)$, using $1 \mathrm{~cm}$ path length cells, without using cut-off filters, at a rate of $100 \mathrm{~nm} / \mathrm{min}$, with constant slit widths, for excitation $(10 \mathrm{~nm})$ and for emission $(6 \mathrm{~nm})$, exciting at $\lambda=365 \mathrm{~nm}$. The fluorescence quantum yield $\left(\Phi_{\mathrm{F}}\right)$ of Pt-porphyrin was calculated by using the steady-state comparative method formula: $\Phi_{\text {sample }}$ $=\Phi_{\mathrm{TPP}}\left(\mathrm{F}_{\text {sample }} / \mathrm{F}_{\mathrm{TPP}}\right)\left(\mathrm{A}_{\mathrm{TPP}} / \mathrm{A}_{\text {sample }}\right)\left(\mathrm{n}_{\text {sample }}{ }^{2} / \mathrm{n}_{\mathrm{TPP}}{ }^{2}\right)$, where $\Phi$ is the relative fluorescence quantum yield, $F, A$, and $n$ are the measured fluorescence area, the absorbance, and the refractive index of the solvent, respectively [21]. The method is based on comparing the Pt-porphyrin emission spectrum area with that of a fluorescence standard, meso-tetraphenylporphyrin (TPP). The emission spectra were performed in THF by exciting at $\lambda \mathrm{ex}=330 \mathrm{~nm}$. A value of $\Phi_{\mathrm{f}}=0.10$ for TPP in THF, previously calculated [22], was used.

FT-IR spectra were carried out on a JASCO 430 FT-IR (Hachioji, Tokyo, Japan), from KBr pellets, in the range $4000-400 \mathrm{~cm}^{-1}$. ${ }^{1} \mathrm{H}-\mathrm{NMR}$ and ${ }^{13} \mathrm{C}$-NMR spectra were registered on $400 \mathrm{MHz}$ and $100 \mathrm{MHz}$ respectively on a Bruker Avance DRX spectrometer equipped with a $5 \mathrm{~mm}$ four nuclei $\left({ }^{1} \mathrm{H} /{ }^{13} \mathrm{C} /{ }^{19} \mathrm{~F} /{ }^{29} \mathrm{Si}\right)$ direct detection probe (Rheinsteitten, Germany), in $\mathrm{CDCl}_{3}$. The chemical shifts are expressed in $\delta$ (ppm). Electrochemical investigations were performed with the help of Autolab 302N EcoChemie (Eco Chemie, The Netherlands, 2007).

\subsection{Synthesis of 5,10,15,20-tetra-(4-allyloxy-phenyl)-porphyrin (TAPP)}

Synthesis of 5,10,15,20-tetra-(4-allyloxy-phenyl)-porphyrin (TAPP) was done by functionalization of tetra-(4-hydroxy-phenyl) porphyrin derivative with bromopropylene [23] or by Lindsey method $[24,25]$ from 4 -allyloxybenzaldehyde and pyrrole. The complete physical characterization of the porphyrin base is in full agreement with the structure and was previously published [26].

\subsection{Synthesis of Pt(II)-5,10,15,20-tetra-(4-allyloxy-phenyl)-porphyrin (Pt(II)-TAPP)}

The synthesis of $\mathrm{Pt}(\mathrm{II})-5,10,15,20$-tetra-(4-allyloxy-phenyl)-porphyrin, shown in Figure 1, was performed by adapting the method of Yamashita [27], optimized according to [28], as follows: $0.105 \mathrm{~g}$ (12.5 mmole) 5,10,15,20-tetra-(4-allyloxy-phenyl)porphyrin dissolved in $35 \mathrm{~mL}$ chlorobenzene were vigorously stirred together with a mixture containing $0.0933 \mathrm{~g}(19.7 \mathrm{mmole}) \mathrm{PtCl}_{2}\left(\mathrm{PhCN}_{2}\right.$ and $0.072 \mathrm{~g}$ (52.9 mmole) $\mathrm{NaAc} \times 3 \mathrm{H}_{2} \mathrm{O}$ dissolved in $24 \mathrm{~mL}$ chlorobenzene. The molar ratio between the reactants was TAPP: $\mathrm{PtCl}_{2}\left(\mathrm{PhCN}_{2}: \mathrm{CH}_{3} \mathrm{COONa} \times 3 \mathrm{H}_{2} \mathrm{O}=1: 1.5: 4\right.$ chosen in order to favor the generation of the Pt-complex and to prevent the $\mathrm{HCl}$ generation. Then, the reaction mixture was refluxed for $2 \mathrm{~h}$ and the reaction progress was monitored by UV-vis spectroscopy, as can be seen in Figure 2.

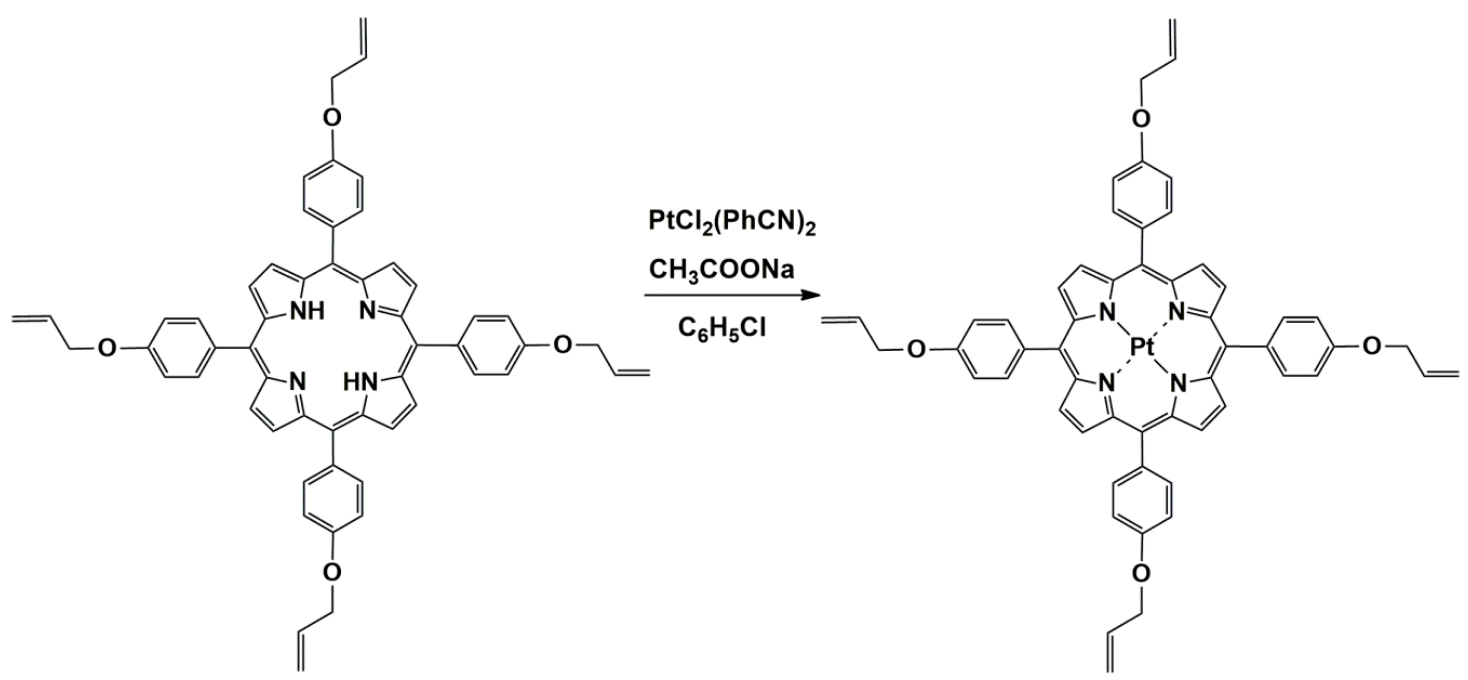

Figure 1. Reaction scheme for obtaining Pt(II)-5,10,15,20-tetra-(4-allyloxy-phenyl)-porphyrin. 
The completion of the reaction was evidenced in the UV-vis spectra by both the hypsochromic shift of the Soret band and the reducing of the $Q$ bands number to only two, as shown in Figure 2. The reaction mixture was then cooled to room temperature, filtered, and repeatedly washed with warm water $(4 \times 60 \mathrm{~mL})$. The filtrate was several times washed with $100 \mathrm{~mL}$ water in a separatory funnel. The organic extract was dried over $\mathrm{Na}_{2} \mathrm{SO}_{4}$ and the chlorobenzene was removed by vacuum distillation. The resulting orange-reddish solid was recrystallized from dichloromethane. The pure crystalline powder was finally kept for $10 \mathrm{~h}$ at $90^{\circ} \mathrm{C}$ in vacuum.

The main characteristics of $\mathrm{Pt}(\mathrm{II})-5,10,15,20$-tetra-(4-allyloxy-phenyl)porphyrin are: brownishorange crystals; yield $86 \%$; mp over $320{ }^{\circ} \mathrm{C} ;{ }^{1} \mathrm{H}-\mathrm{NMR}\left(\mathrm{CDCl}_{3}, 400 \mathrm{MHz}\right), \delta$, ppm: $8.70(\mathrm{~s}, 8 \mathrm{H}, \beta$-pyrrole), 7.94-7.96 (d, $J=8.4 \mathrm{~Hz}, 8 \mathrm{H}, \mathrm{H}-2,6$ phenyl), 7.18-7.20 (d, $J=8.4 \mathrm{~Hz}, 8 \mathrm{H}, \mathrm{H}-3,5$ phenyl), 6.13-6.22 (m, 4H, $\left.\mathrm{O}-\mathrm{CH}_{2}-\mathrm{CH}=\mathrm{CH}_{2}\right), 5.51-5.55\left(\mathrm{~d}, \mathrm{~J}=17.4 \mathrm{~Hz}, 4 \mathrm{H}, \mathrm{O}-\mathrm{CH}_{2}-\mathrm{CH}=\mathbf{H C H}\right), 5.34-5.36(\mathrm{~d}, \mathrm{~J}=10.6 \mathrm{~Hz}, 4 \mathrm{H}$, $\left.\mathrm{O}-\mathrm{CH}_{2}-\mathrm{CH}=\mathrm{HCH}\right), 4.73-4.75\left(\mathrm{~d}, \mathrm{~J}=5.2 \mathrm{~Hz}, 8 \mathrm{H}, \mathrm{O}-\mathrm{CH}_{2}-\mathrm{CH}=\mathrm{HCH}\right)$; the ratio between the peak areas of these proton categories is around: 1:1:1:0.5:0.5:0.5:1. ${ }^{13} \mathrm{C}-\mathrm{NMR}\left(\mathrm{CDCl}_{3}, 100 \mathrm{MHz}\right), \delta, \mathrm{ppm:} 158.49$ $\left(C_{p h}{ }^{1^{\prime}}\right) ; 155.43(C=\mathrm{N}) ; 135.03\left(C_{p h}{ }^{3^{\prime}}\right), 134.88(=\mathrm{CH}) ; 133.39(=\mathrm{CH}) ; 130.62(=\mathrm{CH}) ; 117.99\left(=\mathrm{CH}_{2}\right) ; 113.78$ $(=\mathrm{CH}) ; 113.07\left(C_{p h}{ }^{2^{\prime}}\right) ; 69.16\left(-\mathrm{OCH} \mathrm{H}_{2}\right)$. FT-IR(KBr), $\mathrm{cm}^{-1}: 3426(\mathrm{H}-\mathrm{bonding}), 1640$ and $1501\left(v_{\mathrm{C}=\mathrm{CPh}}\right)$, $1452\left(v_{\mathrm{C}=\mathrm{N}}\right), 1357\left(v_{\mathrm{C}-\mathrm{N}}\right), 1231\left(v_{\mathrm{C}-\mathrm{O}-\mathrm{Cas}}\right), 1168\left(\delta_{\mathrm{C}-\mathrm{HPh}}\right), 1006\left(v_{\mathrm{C}-\mathrm{O}-\mathrm{C}}\right), 791\left(\gamma_{\mathrm{C}-\mathrm{Hpyrrol}}\right), 670\left(\delta_{\mathrm{C}-\mathrm{Hpyrrol}}\right)$; UV-vis, DMSO $\left(\lambda_{\max }(\log \varepsilon)\right): 408.6(5.28) ; 512.5(4.31) ; 596.5(3.44) ; \Phi_{\mathrm{f}}=0.038 \pm 0.009$.

\subsection{Electrochemical Measurements}

Before each electrochemical determination, the working electrode (WE) was cleaned with fine sandpaper $(0.3 \mu \mathrm{m})$, washed with water, electrochemically cleaned (10 cycles in $0.5 \mathrm{M}$ sulfuric acid in the range -1 to $1.2 \mathrm{~V}$ ), and exposed to ultrasound bath for 3 minutes in water, acetone, and ethanol.

The porphyrin films were deposited on clean GCE surfaces by drop-casting from a $5.84 \mathrm{mM}$ $\mathrm{Pt}(\mathrm{II})$-TAPP solution in $\mathrm{CH}_{2} \mathrm{Cl}_{2}$, by successively depositing $3 \times 1$ drops. The films were left to dry, then the surfaces were washed with $\mathrm{CH}_{2} \mathrm{Cl}_{2}$ and water and then dried and stored in the dark. The modified electrode thus prepared was marked as Pt-Porf-GCE. All electrochemical measurements were performed at room temperature in a conventional one-compartment three-electrode cell. The electrochemical cell contains the platinum wire as auxiliary electrode, the $\mathrm{Ag} / \mathrm{AgCl}$ as reference electrode and the working electrode: glassy carbon (GCE $0.0314 \mathrm{~cm}^{2}$ ) unmodified and modified with metal porphyrin film (Pt-Porf-GCE).

The electrocatalytic effect of the Pt-metalloporphyrin on hydrogen peroxide transformation was carried out in morpholine-ethane-sulfonic acid (MES) buffer solution, pH 5.6, at a scan rate of $50 \mathrm{mV} / \mathrm{s}$, in open atmosphere, without removing oxygen (this did not have a significant effect on the oxidation process) [20].

\section{Results and Discussion}

\subsection{UV-vis Monitoring of the Metalation Reaction}

As represented in Figure 2, the UV-vis spectrum of the (TAPP) porphyrin-base is etio type shape with the Soret band generated by the transition from $\mathrm{a}_{1 \mathrm{u}}(\pi)-\mathrm{e}_{\mathrm{g}}{ }^{*}(\pi)$ and the four Q-bands in the visible region, corresponding to $\mathrm{a}_{2 \mathrm{u}}(\pi)-\mathrm{e}_{\mathrm{g}}{ }^{*}(\pi)$ transitions.

Monitoring the metalation reaction by UV-vis, as represented in Figure 2, shows that after a short period of time the Soret band of TAPP is splitting into two bands of equal intensity, revealing the equilibrium between porphyrin base $(\lambda=425 \mathrm{~nm})$ and the generation of $\mathrm{Pt}(\mathrm{II})$-TAPP. The forming of Pt-TAPP is shown by the significant hypsochromic shift of the Soret band with $15 \mathrm{~nm}$, to $410 \mathrm{~nm}$. After 100 min of reflux, the QI and the QIII bands disappeared and the intensity of the Soret band located at $410 \mathrm{~nm}$ is continuously increasing, proving that the equilibrium of the reaction is moved to the formation of the Pt-complex. 


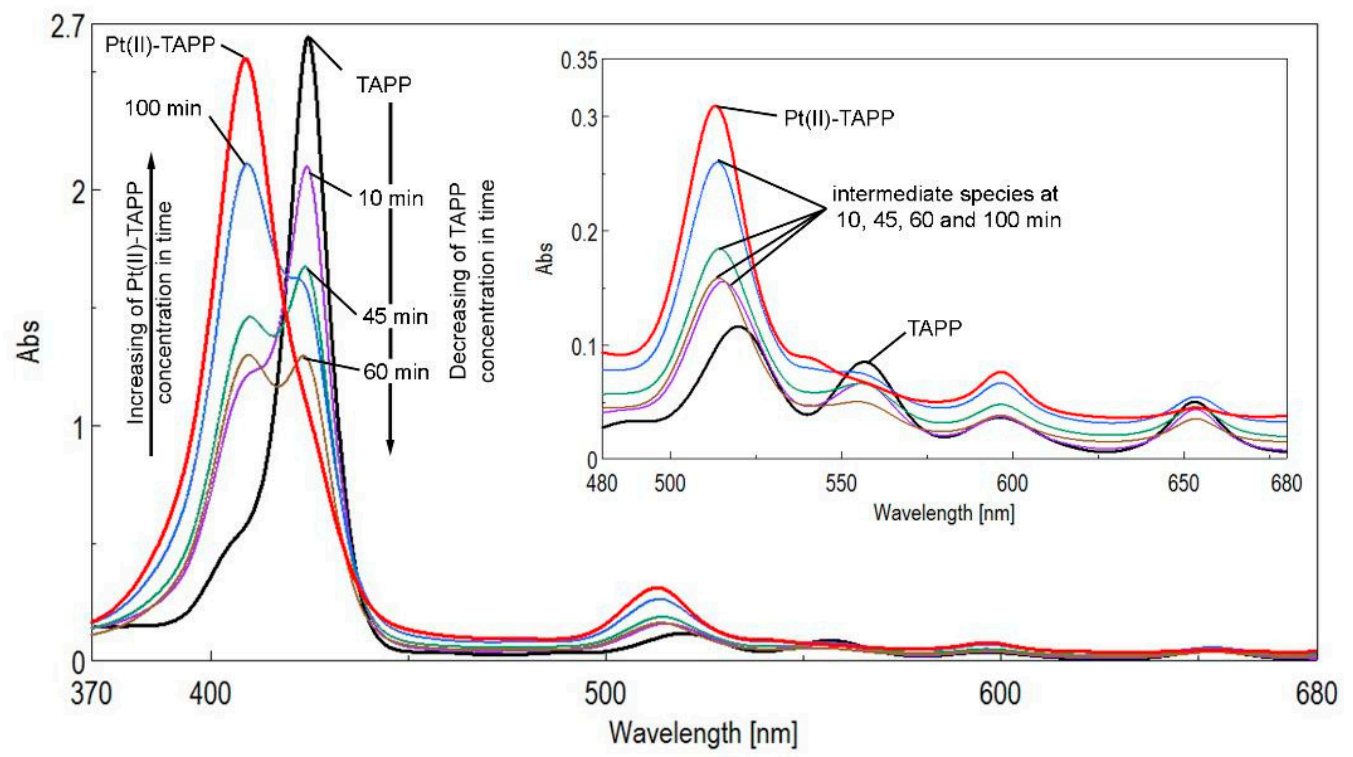

Figure 2. Monitoring the reaction progress of forming Pt(II)-TAPP by increasing the absorption intensity at $410 \mathrm{~nm}$ and decreasing the intensity of the TAPP absorption bands at $425 \mathrm{~nm}$. In detail the differences between the $\mathrm{Q}$ bands of TAPP, Pt(II)-TAPP and intermediate species.

The reaction was completed after approximately two hours, when all the porphyrin was transformed into its Pt-complex. As a consequence, UV-vis spectrum presents solely a narrow Soret band located at $410 \mathrm{~nm}$ and only two Q bands, the first located at $513 \mathrm{~nm}$, blue shifted in comparison with the porphyrin base and representing the $Q(0-1)$ vibration and the second one at $596 \mathrm{~nm}$ respectively, representing $\mathrm{Q}(0-0)$ electronic transition. The intensity of the remaining $\mathrm{Q}(0-0)$ band is increased as compared to the original QI(0-0) band of the porphyrin base. According to this behavior [29] the novel obtained Pt-porphyrin is belonging to the second group of metalloporphyrins.

\subsection{Physicochemical Characterization of Pt(II)-5,10,15,20-tetra-(4-allyloxy-phenyl)-porphyrin}

\subsubsection{FT-IR Characterization}

A comparison of the FT-IR spectra of the porphyrin base TAPP with the corresponding Pt(II)-TAPP, as presented in Figure 3, shows that the Pt-complex gave a simplified spectrum, due to the higher symmetry of the novel compound, which increases from $\mathrm{D}_{2 \mathrm{~h}}$ to $\mathrm{D}_{4 \mathrm{~h}}$.

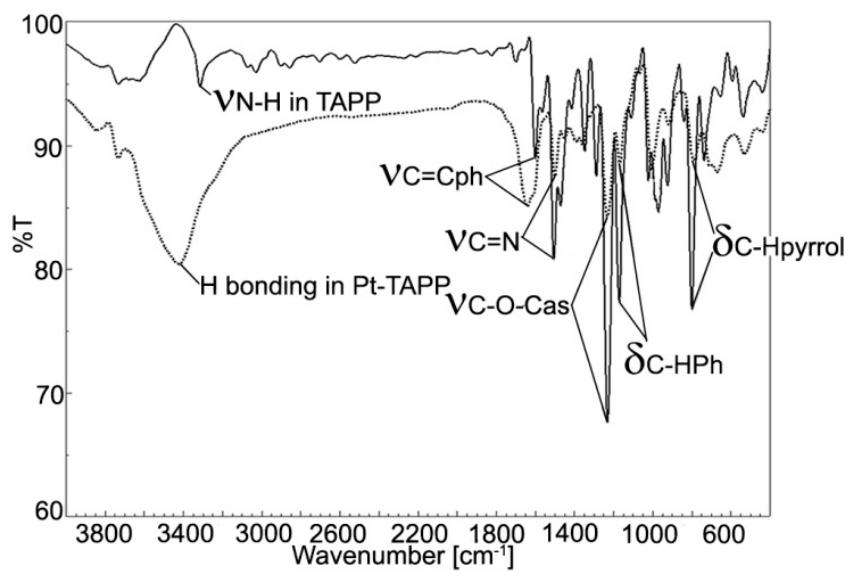

Figure 3. Overlapped FT-IR spectra for TAPP (full line) and Pt(II)-TAPP (dotted line). 
The peak located at $3318 \mathrm{~cm}^{-1}$ and attributed to internal N-H bond is no more present in the $\mathrm{Pt}$ (II)-TAPP spectrum, proving the complete metalation. Due to the increased symmetry, the band corresponding to C-H stretching and bending vibrations, located at $1289 \mathrm{~cm}^{-1}$ in the spectrum of the porphyrin base is missing in the case of Pt-porphyrin. The large band of $\mathrm{OH}$ group caused by intramolecular $\mathrm{H}$-bonding and located at $3426 \mathrm{~cm}^{-1}$ covers the $\mathrm{C}-\mathrm{H}$ stretching vibrations of phenyl ring from $3033 \mathrm{~cm}^{-1}$ [30]. The $\mathrm{C}=\mathrm{N}$ bonding vibration has a lower frequency $\left(1452 \mathrm{~cm}^{-1}\right)$ in $\mathrm{Pt}$ (II)-TAPP than in the porphyrin base $\left(1472 \mathrm{~cm}^{-1}\right)$ due to the influence of the platinum atom [31,32]. Another significant band is the vibration of the C-O-C bond, located at $1006 \mathrm{~cm}^{-1}$ in the Pt-porphyrin [33].

\subsubsection{NMR Analysis}

The investigation of the ${ }^{1} \mathrm{H}-\mathrm{NMR}$ spectrum, represented in Figure $4 \mathrm{~A}$, reveals the absence of the signal of the two internal protons, proving the bonding of the platinum in the inner core of the porphyrin. All the signals for the distinctive protons that prove the proposed structure of the compound are identifiable. Thus, the $\beta$-pyrrolic protons present a singlet at $8.70 \mathrm{ppm}$; the eight ortho phenyl protons gave signal in the 7.94-7.96 ppm interval and the eight meta phenyl protons as doublet at 7.18-7.20 ppm, respectively. The four protons from $\mathrm{O}-\mathrm{CH}_{2}-\mathrm{CH}=\mathrm{CH}_{2}$ are identified as multiplet at 6.13-6.22 ppm, the other eight belonging to $=\mathrm{CH}_{2}$ are resonating as two doublets from 5.51 to $5.55 \mathrm{ppm}$ and from 5.34 to $5.36 \mathrm{ppm}$; the protons in the vicinity of oxygen $\mathrm{O}-\mathrm{CH}_{2}$ - gave a doublet at 4.73-4.74 ppm.

The chemical shifts $(\delta)$ of ${ }^{13} \mathrm{C}-\mathrm{NMR}$ are attributed in Figure $4 \mathrm{~B}$, taking into consideration the distinct aspect and zone for the assignment of each carbon. The 3-line triplet signal around 77 is due to $\mathrm{CDCl}_{3}$ in which the sample was diluted.
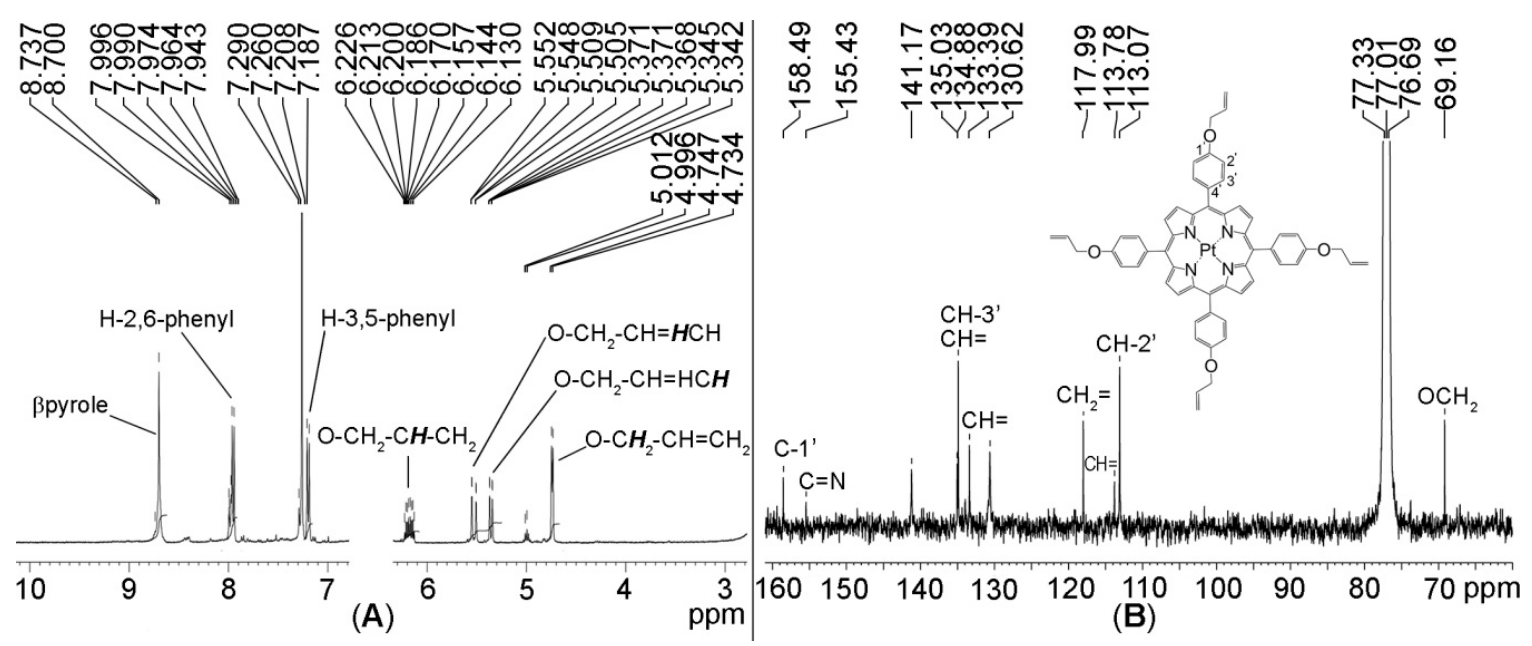

Figure 4. (A) ${ }^{1} \mathrm{H}-\mathrm{NMR}$ spectrum and (B) ${ }^{13} \mathrm{C}-\mathrm{NMR}$ spectrum of $\mathrm{Pt}(\mathrm{II})-\mathrm{TAPP}$ in $\mathrm{CDCl}_{3}$.

\subsection{Detection of $\mathrm{H}_{2} \mathrm{O}_{2}$}

\subsubsection{Fluorimetric Detection of $\mathrm{H}_{2} \mathrm{O}_{2}$}

The method for testing the capacity of Pt(II)-TAPP to act as a sensitive material for the fluorimetric detection of hydrogen peroxide was performed by adding $0.6 \mathrm{~mL} \mathrm{H} \mathrm{H}_{2} \mathrm{O}_{2}$ solution with different concentrations to each sample containing $5.4 \mathrm{~mL}$ solution of $9.93 \times 10^{-6} \mathrm{M} \mathrm{Pt}$ (II)-TAPP in DMSO. The concentrations of the added $\mathrm{H}_{2} \mathrm{O}_{2}$ solution were: $1.05 \times 10^{-6} \mathrm{M} ; 1.1 \times 10^{-6} \mathrm{M} ; 1.6 \times 10^{-6} \mathrm{M}$; $2.59 \times 10^{-6} \mathrm{M} ; 2.9 \times 10^{-6} \mathrm{M} ; 3.17 \times 10^{-6} \mathrm{M} ; 3.43 \times 10^{-6} \mathrm{M} ; 3.67 \times 10^{-6} \mathrm{M} ; 3.9 \times 10^{-6} \mathrm{M}$. Each sample was stirred, and the emission spectra were recorded, as shown in Figure 5. 


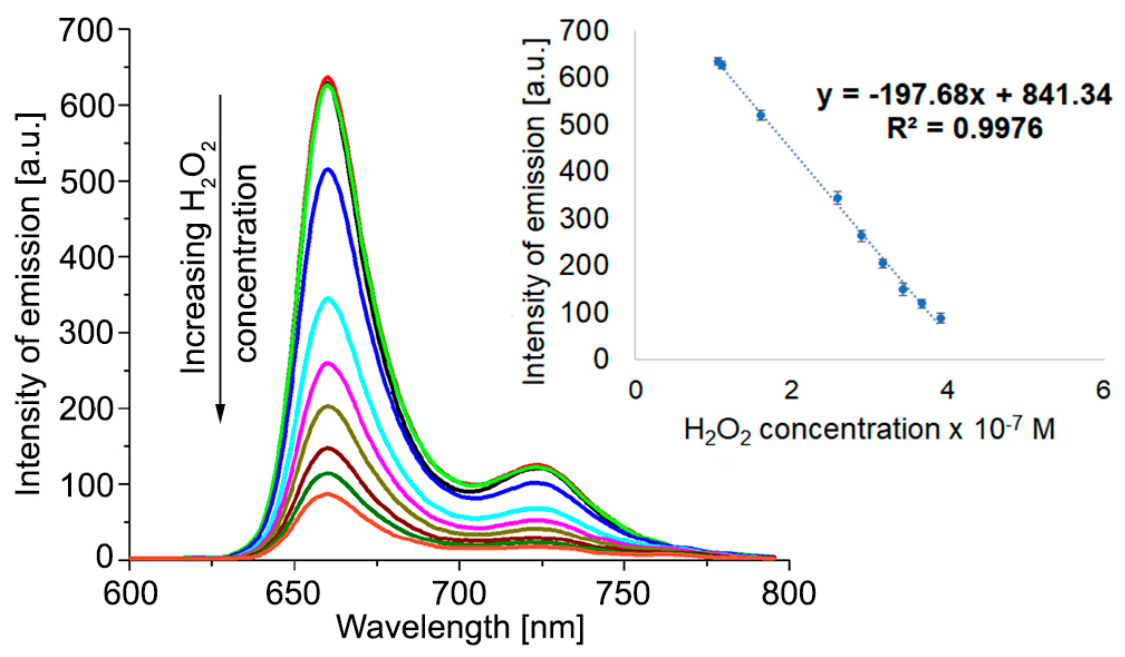

Figure 5. Effect of $\mathrm{H}_{2} \mathrm{O}_{2}$ on the fluorescence spectra of Pt(II)-TAPP, recorded in DMSO. Linear dependence between the intensity of emission of $\mathrm{Pt}(\mathrm{II})-\mathrm{TAPP}$, read at $660 \mathrm{~nm}$, and the $\mathrm{H}_{2} \mathrm{O}_{2}$ concentration.

It can be observed that the quenching of fluorescence is taking place when adding hydrogen peroxide to the $\mathrm{Pt}(\mathrm{II})$-TAPP solution in DMSO, as represented in Figure 5. The intensity of emission decreases after a linear equation, characterized by an excellent confidence coefficient of $99.76 \%$, in 1.05-3.9 $\times 10^{-7} \mathrm{M} \mathrm{H}_{2} \mathrm{O}_{2}$ concentration range.

Study of Interfering Analytes

The selectivity of the fluorimetric sensor toward the $\mathrm{H}_{2} \mathrm{O}_{2}$ detection is a very important aspect. Taking into consideration that this fluorimetric sensor is destined for medical tests, the interference study, shown in Figure 6, was focused on those anions, cations or compounds that are frequently present in the targeted environments (human serum and urine), such as: glucose (Glu); $\mathrm{NaCl}$; ascorbic acid (AA); phosphate buffer (PSB), $\mathrm{AA}+\mathrm{NaCl}, \mathrm{PSB}+\mathrm{NaCl}, \mathrm{Glu}+\mathrm{NaCl}$, lactic acid (LA), $\mathrm{I}_{2}+\mathrm{LA}$, potassium dichromate $\left(\mathrm{Cr}_{2} \mathrm{O}_{7}{ }^{2-}\right), \mathrm{Cr}_{2} \mathrm{O}_{7}{ }^{2-}+\mathrm{LA}$, acetic acid (AcA), potassium permanganate $\left(\mathrm{MnO}_{4}{ }^{-}\right), \mathrm{MnO}_{4}{ }^{-}+$ $\mathrm{LA}$, dilauryl phosphite (LP), $\mathrm{LP}+\mathrm{NaCl}[28,34-36]$. The concentration of each potential interfering analyte was $2 \times 10^{-4} \mathrm{M}, 100$-fold higher in the mixed solution than that of $\mathrm{H}_{2} \mathrm{O}_{2}\left(\mathrm{c}=2 \times 10^{-6} \mathrm{M}\right)$.

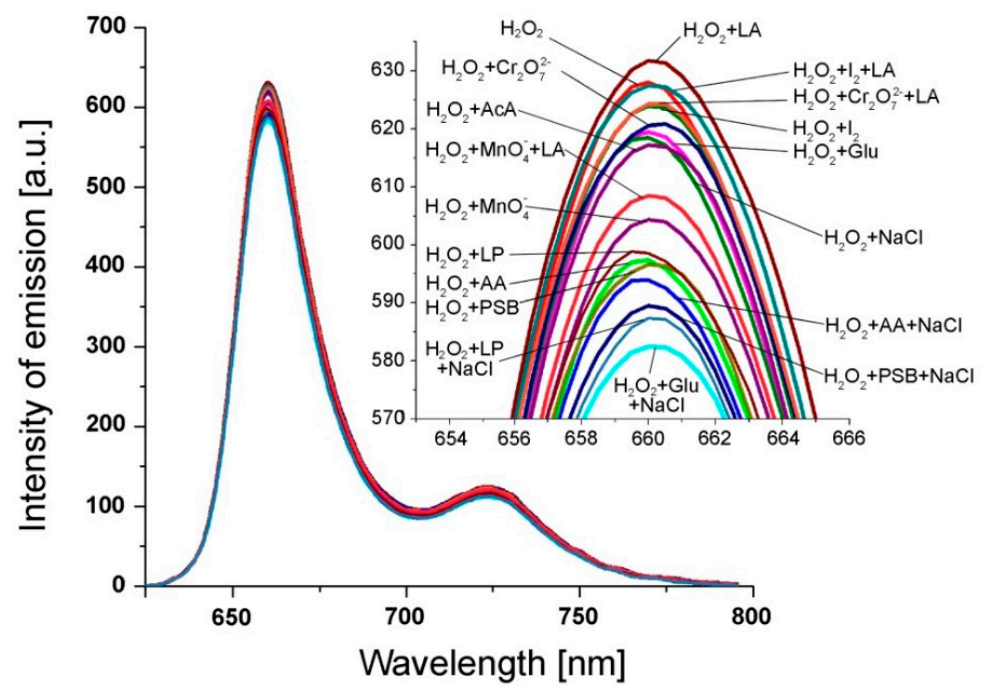

Figure 6. Fluorescence spectra of $\mathrm{Pt}(\mathrm{II})-\mathrm{TAPP}$ containing $\mathrm{H}_{2} \mathrm{O}_{2}\left(\mathrm{c}=2 \times 10^{-6} \mathrm{M}\right)$ in DMSO and in the presence of different interference analytes: $\mathrm{LA} ; \mathrm{I}_{2}+\mathrm{LA} ; \mathrm{Cr}_{2} \mathrm{O}_{7}{ }^{2-}+\mathrm{LA}_{2} \mathrm{I}_{2} ; \mathrm{Cr}_{2} \mathrm{O}_{7}{ }^{2-} ; \mathrm{Glu} ; \mathrm{NaCl} ; \mathrm{AcA}$; $\mathrm{MnO}_{4}{ }^{-}+\mathrm{LA} ; \mathrm{MnO}_{4}{ }^{-} ; \mathrm{LP} ; \mathrm{AA} ; \mathrm{PSB} ; \mathrm{AA}+\mathrm{NaCl} ; \mathrm{PSB}+\mathrm{NaCl} ; \mathrm{LP}+\mathrm{NaCl} ; \mathrm{Glu}+\mathrm{NaCl}$. The concentration of each potential interfering analyte was $2 \times 10^{-4} \mathrm{M}$. 
The method used for investigation of interfering analytes is described as follows: to each $10 \mathrm{~mL}$ of $9.93 \times 10^{-6} \mathrm{M} \mathrm{Pt}(\mathrm{II})$-TAPP solution in DMSO, $1 \mathrm{~mL}$ solution containing the mentioned above interfering analytes was added. Each sample was vigorously stirred for 1 minute in the ultrasonic bath and the fluorescence spectra were recorded. Each measurement was performed three times.

The average percentage errors for $\mathrm{H}_{2} \mathrm{O}_{2}$ fluorescence detection are calculated as $\mid \Delta \mathrm{I} / / \mathrm{I} \times 100$ (where I represents the emission intensity of the sample containing $\mathrm{H}_{2} \mathrm{O}_{2}$ and $|\Delta \mathrm{I}|$, the difference in module between I and the emission intensity of each studied interference analyte or mixtures of analytes), as displayed in Figure 7.

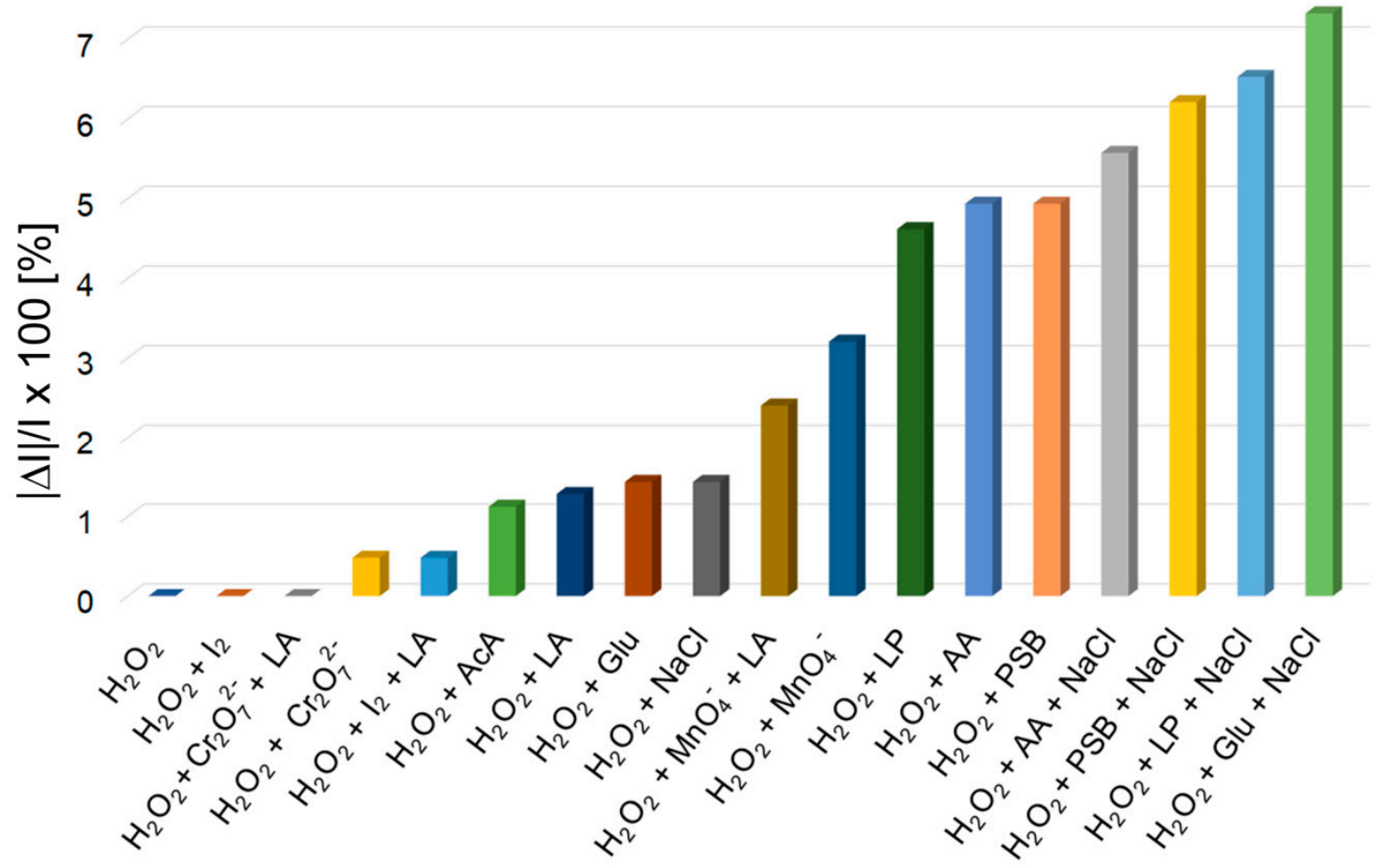

Figure 7. Average percentage errors for $\mathrm{H}_{2} \mathrm{O}_{2}$ fluorescence detection, introduced by different interferences, after three determinations.

As can be seen from Figure 7, glucose, lactic acid, dichromate anion, iodine, acetic acid, $\mathrm{NaCl}$ and permanganate anion, solely or in combined mixtures, have no significant influence toward $\mathrm{H}_{2} \mathrm{O}_{2}$ detection, although their concentration was 100-times higher than the concentration of detected $\mathrm{H}_{2} \mathrm{O}_{2}$.

Other interferences, such as: ascorbic acid, dilauryl phosphite and phosphate buffer introduced significant average percentage errors, below 5\%. Instead, by performing the measurements in samples comprising at least three different interference analytes, each of them containing $\mathrm{NaCl}$, the measurements are lacking in precision (errors between $5.5 \%$ and $7.3 \%$ ), probably because of the induced higher ionic strength.

\subsubsection{Electrochemical Detection of $\mathrm{H}_{2} \mathrm{O}_{2}$}

The response of GCE and GCE electrodes modified with Pt-porphyrin film (Pt-Porf-GCE) in MES buffer solution at $\mathrm{pH}=5.6$ was studied comparatively. The cyclic voltammograms are shown in Figure 8A. Different cyclic voltammograms were obtained on modified GCE electrode. The modified electrode has oxidation peaks at the potentials of $0.35 \mathrm{~V}$ and $0.8 \mathrm{~V}$ and reduction peaks at $-0.125 \mathrm{~V}$ and $-0.6 \mathrm{~V}$, corresponding to the Pt-porphyrin film and thus confirming its presence on the electrode surface. 

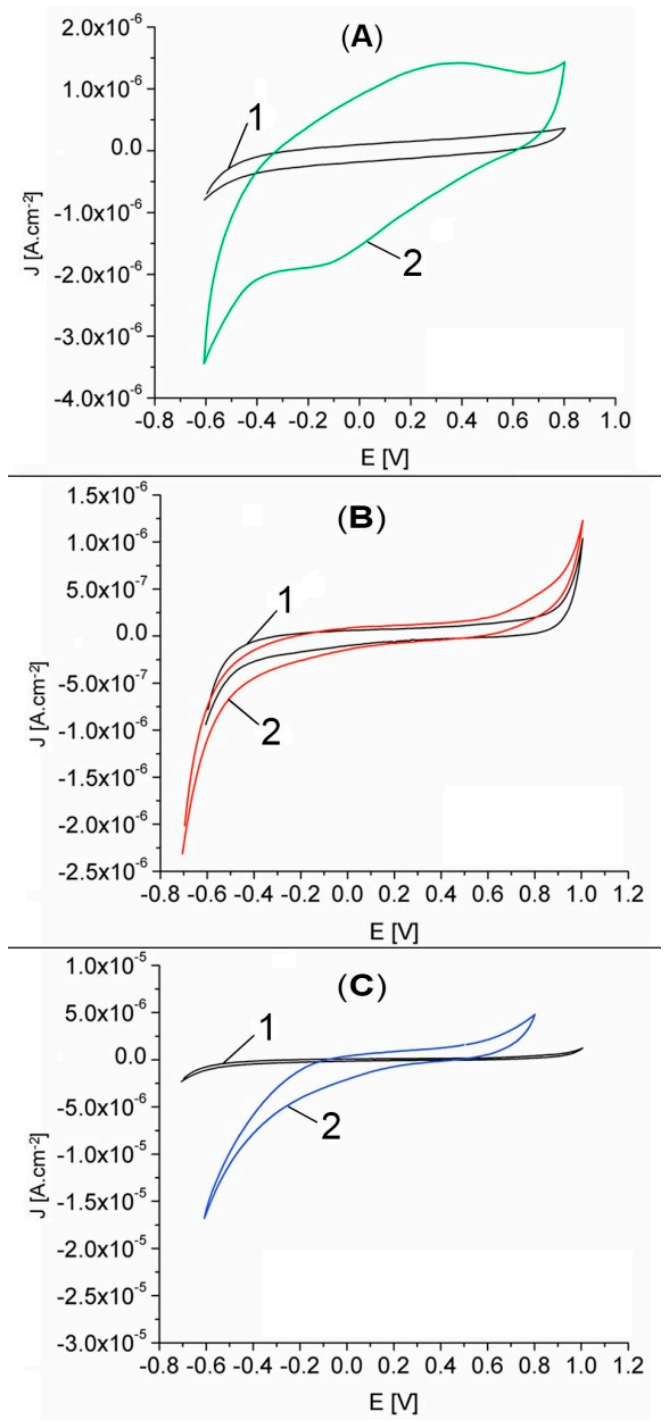

Figure 8. Cyclic voltammograms recorded in MES phosphate buffer solution, $\mathrm{pH}=5.6,50 \mathrm{mV} / \mathrm{s}, 25^{\circ} \mathrm{C}$, for: (A) GCE (curve 1) and Pt-Porf-GCE (curve 2), cycle 3; (B) GCE in the absence (curve 1) and in the presence of $28.95 \mathrm{mM} \mathrm{H}_{2} \mathrm{O}_{2}$ (curve 2); (C) GCE (curve 1) and Pt-Porf-GCE (curve 2) in the presence of $28.95 \mathrm{mM} \mathrm{H}_{2} \mathrm{O}_{2}$.

Cyclic voltammograms for GCE in MES buffer solution at $\mathrm{pH}=5.6$ in the absence and in the presence of $\mathrm{H}_{2} \mathrm{O}_{2}$, are presented in Figure 8B. The GCE presents a light response in the presence of $\mathrm{H}_{2} \mathrm{O}_{2}$. The comparison of the cyclic voltammograms shown in Figure 8C for GCE (curve 1) and for modified Pt-Porf-GCE (curve 2) in the presence of the same concentration of $\mathrm{H}_{2} \mathrm{O}_{2}(28.95 \mathrm{mM})$, reveals that the GCE has no significant response but the modified Pt-Porf-GCE strongly changed both its anodic and cathodic responses. On modified Pt-Porf-GCE the oxidation process takes place at a lower potential and the reduction process at a higher potential than in the case of GCE.

The oxidation current of $\mathrm{H}_{2} \mathrm{O}_{2}$ on the modified Pt-Porf-GCE, represented in Figure 9, increased due to electrocatalytic oxidation $(\sim 0.7 \mathrm{~V})$, as well as that of reduction $(-0.5 \mathrm{~V})$. 


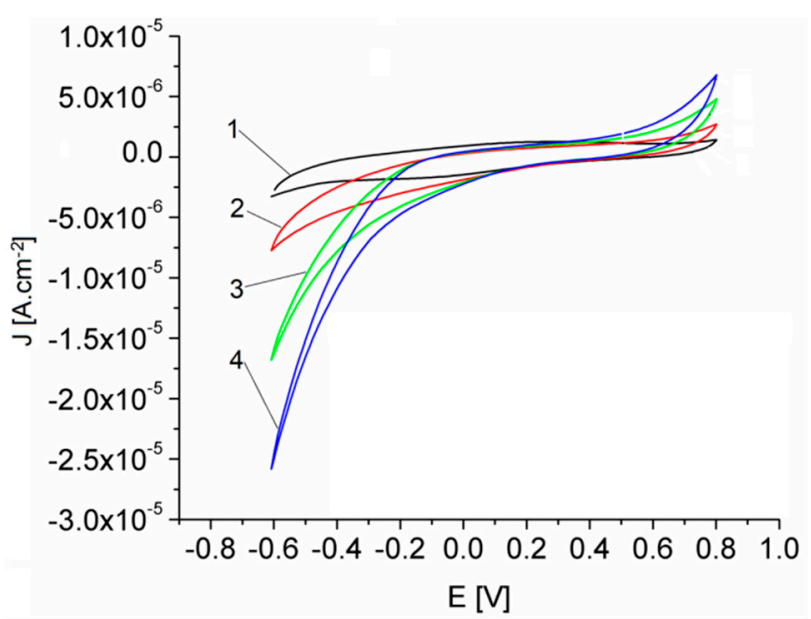

Figure 9. Cyclic voltammograms obtained in MES buffer solution, $\mathrm{pH}=5.6$ for the Pt-Porf-GCE using different concentrations of $\mathrm{H}_{2} \mathrm{O}_{2}$ [mM]: 9.65 (1); 19.3 (2); 28.95 (3); 48.25 (4). $50 \mathrm{mV} / \mathrm{s}, 25{ }^{\circ} \mathrm{C}$.

The significant increase of the reduction current in the presence of $\mathrm{H}_{2} \mathrm{O}_{2}$ is due to the electrocatalytic effect of the Pt-metalloporphyrin (Pt-Porf) on the $\mathrm{H}_{2} \mathrm{O}_{2}$ reduction, illustrated by Equations (1) and (2). The reduced form of Pt-metalloporphyrin (Pt-Porf ${ }^{-}$) can reduce the $\mathrm{H}_{2} \mathrm{O}_{2}$ and transforms into the initial form (Pt-Porf) on the electrode surface (Equation (2)).

$$
\begin{gathered}
\text { Pt-Porf }+\mathrm{e} \longrightarrow \text { Pt-Porf }^{-} \\
2 \text { Pt-Porf }^{-}+\mathrm{H}_{2} \mathrm{O}_{2}+2 \mathrm{H}^{+} \longrightarrow 2 \mathrm{Pt} \text {-Porf }+2 \mathrm{H}_{2} \mathrm{O}
\end{gathered}
$$

The oxidation current is due to the electrochemical oxidation of water and hydrogen peroxide. The hydrogen peroxide oxidation is mediated by the Pt-metalloporphyrin immobilized on the GCE, as can be seen in the following simplified mechanism, presented in Equations (3) and (4):

$$
\begin{gathered}
\text { Pt-Porf } \longrightarrow \text { Pt-Porf }{ }^{+}+\mathrm{e} \\
2 \text { Pt-Porf }^{+}+\mathrm{H}_{2} \mathrm{O}_{2} \longrightarrow 2 \text { Pt-Porf }+\mathrm{O}_{2}+2 \mathrm{H}^{+}
\end{gathered}
$$

Similar observations were reported by other authors [4,37].

In the studied concentration range, the anodic and cathodic response currents of the Pt-Porf-GCE are directly proportional to the $\mathrm{H}_{2} \mathrm{O}_{2}$ concentration, as illustrated in Figure 10A,B).
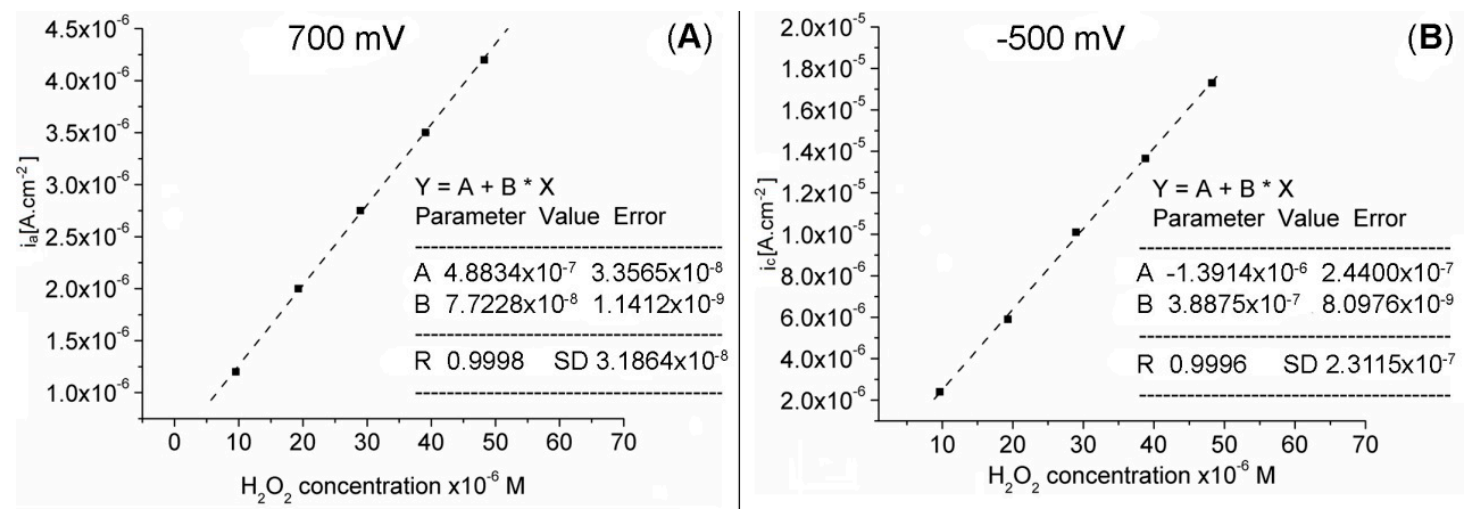

Figure 10. Linear dependence between (A) anodic current at $700 \mathrm{mV}$ (R: 0.9998, SD: $3.1864 \times 10^{-8}$ ) and (B) cathodic current at $-500 \mathrm{mV}$ (R: 0.9996, SD: $2.3115 \times 10^{-7}$ ) on the Pt-Porf-GCE and the concentration of hydrogen peroxide, in MES buffer solution, at $50 \mathrm{mV} / \mathrm{s}, 25^{\circ} \mathrm{C}$. 
The results indicate that the detection of hydrogen peroxide by using the modified Pt-Porf-GCE is accurate. The oxidation and reduction currents were found to increase linearly with increasing $\mathrm{H}_{2} \mathrm{O}_{2}$ concentration. The calibration graphs from Figure 10A, B, plotted between the catalytic current and $\mathrm{H}_{2} \mathrm{O}_{2}$ concentration on the Pt-Porf-GCE give a linear dependence in the concentration range from $1 \times 10^{-6} \mathrm{M}$ to $5 \times 10^{-5} \mathrm{M}, \mathrm{R}^{2}=0.999$, for both diagrams.

This is a range of concentration larger than that obtained in the case of fluorimetric detection and is appropriate for measurements in technical gold cyanidation [38] cosmetics [39] and agriculture [10].

\section{Conclusions}

Metalloporphyrins(II) are highly recognized for their capacity to act as sensitive substances used in formulation of optical, fluorescent, and electrochemical sensors. In this respect, a novel Pt-porphyrin structure, namely: Pt(II)-5,10,15,20-tetra-(4-allyloxy-phenyl) porphyrin, was successfully synthesized and was fully characterized by UV-vis and fluorimetry (Supplementary Materials), FT-IR, ${ }^{1} \mathrm{H}-\mathrm{NMR}$ and ${ }^{13} \mathrm{C}$-NMR methods.

The fluorescence response of this Pt-porphyrin in the presence of different concentrations of hydrogen peroxide was investigated. It was proved that in the detection domain $1.05-3.9 \times 10^{-7} \mathrm{M}$ $\mathrm{H}_{2} \mathrm{O}_{2}$ (that is highly relevant for biological testing) the investigated porphyrin can act as fluorescent sensitive substance, with a high confidence coefficient of $99.7 \%$. In comparison with other previous strategies $[8,16,17]$, this fluorescent approach gave a 40 times lower detection limit of $0.3 \times 10^{-7} \mathrm{M}$, and the procedure is simpler, less expensive and less time consuming. The fluorimetric response is accurate and stable in the presence of several interfering mixtures of anions, cations and strongly oxidizing species frequently present in the targeted environments. Glucose, lactic acid, dichromate anion, iodine, acetic acid, $\mathrm{NaCl}$, and permanganate anion, solely or in combined mixtures, have no significant influence on $\mathrm{H}_{2} \mathrm{O}_{2}$ detection, although their concentration was 100-times higher than that of detected $\mathrm{H}_{2} \mathrm{O}_{2}$.

On the other hand, Pt-Porf-GCE was realized and several electrochemical characterizations were comparatively performed with the bare GCE, in the absence or presence of hydrogen peroxide. The oxidation and reduction currents were found to increase linearly with increasing $\mathrm{H}_{2} \mathrm{O}_{2}$ concentration on modified Pt-Porf-GCE. The calibration graphs plotted between the catalytic current (both anodic and cathodic currents) and $\mathrm{H}_{2} \mathrm{O}_{2}$ concentration on the Pt-Porf-GCE gave a linear response in the concentration range from $1 \times 10^{-6} \mathrm{M}$ to $5 \times 10^{-5} \mathrm{M}$ with exceptional confidence coefficient of $99.9 \%$.

Different methods for the determination of hydrogen peroxide, based on several sensitive materials were accomplished in order to improve the linear concentration range and the limit of detection and are summarized in Table 1.

Table 1. Linear concentration ranges and detection limits of recently developed electrochemical and optical sensors for the determination of hydrogen peroxide, using different sensitive materials.

\begin{tabular}{|c|c|c|c|c|}
\hline Sensitive Material & Detection Method & $\begin{array}{c}\text { Linear } \\
\text { Concentration } \\
\text { Range }(\mu \mathrm{M})\end{array}$ & $\begin{array}{l}\text { Detection } \\
\text { Limit }(\mu \mathrm{M})\end{array}$ & Reference \\
\hline Graphene Sheets- $\mathrm{CeO}_{2} / \mathrm{Au}$ & $\begin{array}{l}\text { Voltammetric } \\
\text { sensing }\end{array}$ & $1-10$ & 0.26 & {$[40,41]$} \\
\hline $\begin{array}{l}\text { Pd and Au nanoparticles } \\
\quad \text { (ratio } 70: 30 \% \text { ) /GCE }\end{array}$ & $\begin{array}{l}\text { Electroreduction of } \\
\text { hydrogen peroxide }\end{array}$ & $10-1270$ & 7.06 & {$[42]$} \\
\hline $\mathrm{Au}$ and Ag nanoparticles/GCE & $\begin{array}{l}\text { Electroreduction of } \\
\text { hydrogen peroxide }\end{array}$ & $5-10$ & 1.3 & {$[43]$} \\
\hline $\begin{array}{l}\text { Thin layers of ruthenium/rhodium/Au } \\
\text { foils }\end{array}$ & $\begin{array}{l}\text { Amperometric } \\
\text { detection-anodic } \\
\text { oxidation }\end{array}$ & $1-500$ & - & [44] \\
\hline $\begin{array}{l}\text { L-Methionine cobalt (II) } \\
\text { phthalocyanine } \\
\text { functionalized MWCNTs/GCE }\end{array}$ & $\begin{array}{l}\text { Amperometric } \\
\text { detection }\end{array}$ & $0.1-0.8$ & 0.05 & {$[45]$} \\
\hline
\end{tabular}


Table 1. Cont.

\begin{tabular}{|c|c|c|c|c|}
\hline Sensitive Material & Detection Method & $\begin{array}{c}\text { Linear } \\
\text { Concentration } \\
\text { Range }(\mu \mathrm{M})\end{array}$ & $\begin{array}{l}\text { Detection } \\
\text { Limit }(\mu \mathrm{M})\end{array}$ & Reference \\
\hline $\begin{array}{l}\text { 4-Nitrophenyl boronic acid or its } \\
\text { pinacol ester }\end{array}$ & $\begin{array}{l}\text { Direct colorimetric } \\
\text { detection }\end{array}$ & $5-50$ & 1 & [46] \\
\hline Pd-Au nanowire sensors & $\begin{array}{l}\text { Non-enzymatic } \\
\text { hydrogen peroxide } \\
\text { reduction }\end{array}$ & $1-1000$ & 0.3 & [47] \\
\hline $\begin{array}{l}\text { Bioconjugates of Au nanoclusters } \\
\text { with Horseradish peroxidase }\end{array}$ & $\begin{array}{l}\text { Luminescence } \\
\text { quenching of } \mathrm{Au}\end{array}$ & $0.1-100$ & 0.03 & [48] \\
\hline $\begin{array}{l}\mathrm{Fe}_{3} \mathrm{O}_{4} \text { and } \mathrm{CdTe} \text { core-shell } \\
\text { nanocomposites }\end{array}$ & $\begin{array}{l}\text { Quenching of } \\
\text { luminescence of } \\
\text { quantum dots }\end{array}$ & $100-1000$ & 35 & [49] \\
\hline $\begin{array}{c}\mathrm{Eu}^{3+} \text {-tetracycline -polyacrylonitrile- } \\
\text { polyacrylamide hybrid }\end{array}$ & $\begin{array}{l}\text { Increasing of } \\
\text { luminescence }\end{array}$ & $0.45-10$ & 0.45 & [50] \\
\hline Zinc porphyrin-fullerene-derivative & $\begin{array}{c}\text { Nonenzymatic } \\
\text { electrochemical sensor }\end{array}$ & $35-3400$ & 1.44 & [51] \\
\hline \multirow{2}{*}{ Platinum-porphyrin/GCE } & $\begin{array}{l}\text { Quencing of } \\
\text { fluorescence }\end{array}$ & $0.1-0.39$ & 0.03 & \multirow{2}{*}{ This work } \\
\hline & $\begin{array}{l}\text { Nonenzymatic } \\
\text { electrochemical sensor }\end{array}$ & $1-50$ & 0.3 & \\
\hline
\end{tabular}

Based on two different fluorimetric and electrochemical methods, this Pt-porphyrin has the potential to cover detection of hydrogen peroxide in diverse fields, from medical tests to technical, cosmetics, food, and agriculture monitoring, with high accuracy. The future implications will be focused on obtaining of the Pt-porphyrin from recovered platinum from spent automotive catalysts producing added value from this recovery and decreasing costs.

Supplementary Materials: The following are available online at http://www.mdpi.com/2227-9040/8/2/29/s1, Figure S1: UV-vis spectra of $\mathrm{Pt}(\mathrm{II})$-TAPP (the same concentration $3 \times 10^{-5} \mathrm{M}$ ) in different solvents: hexane (1); chlorobenzene (2); tetrahydrofuran (3); chloroform (4); dichloromethane (5); benzonitrile (6); dimethylformamide (7); dimethylsulfoxide (8). Effect of the solvent polarity on the intensity and position of the bands, Figure S2: Effect of the solvent polarity on the position and intensity of the bands in fluorescence spectra of Pt(II)-TAPP (the same concentration $3 \times 10^{-5} \mathrm{M}$ ), in: hexane (1); chlorobenzene (2); tetrahydrofuran (3); chloroform (4); dichloromethane (5); benzonitrile (6); dimethylformamide (7); dimethylsulfoxide (8).

Author Contributions: E.F.-C. contributed with conception and design of the study; E.F.-C., N.P. and G.F.-C. established the specific methodology; I.F., D.A. and C.E. organized the database; A.L., M.C., D.A., C.E., I.F. and C.I. performed the synthesis, analyses and investigations; N.P. and G.F.-C. performed and validated the electrochemical experiments; E.F.-C. and M.C. provided resources; E.F.-C., N.P., A.L. and G.F.-C. wrote the first draft of the manuscript; E.F.-C. supervised final editing and managed project. All authors have read and agreed to the published version of the manuscript.

Funding: This research was funded by UEFISCDI, grant number 76 PCCDI/2018 Project belonging to PNIII-Future and Emerging Technologies and partially by Romanian Academy through Programme 3/2020 from "Coriolan Dragulescu" Institute of Chemistry.

Conflicts of Interest: The authors declare that the research was conducted in the absence of any commercial or financial relationships that could be construed as a potential conflict of interest.

\section{References}

1. Sangeetha, N.S.; Narayanan, S.S. Amperometric $\mathrm{H}_{2} \mathrm{O}_{2}$ sensor based on gold nanoparticles/poly (celestine blue) nanohybrid film. SN Appl. Sci. 2019, 1, 732. [CrossRef]

2. Forman, H.J.; Bernardo, A.; Davies, K.J.A. What is the concentration of hydrogen peroxide in blood and plasma? Arch. Biochem. Biophys. 2016, 603, 48-53. [CrossRef] [PubMed]

3. Yuen, J.W.M.; Benzie, I.F.F. Hydrogen peroxide in urine as a potential biomarker of whole body oxidative stress. Free Radic. Res. 2003, 37, 1209-1213. [CrossRef] [PubMed] 
4. Mirabello, V.; Cortezon-Tamarit, F.; Pascu, S.I. Oxygen Sensing, Hypoxia Tracing and in Vivo Imaging with Functional Metalloprobes for the Early Detection of Non-communicable Diseases. Front. Chem. 2018, 6, 27. [CrossRef] [PubMed]

5. Nwose, E.U.; Bwititi, P.T.; Chalada, M.J. Influence of Anticoagulants on Determination of $\mathrm{H}_{2} \mathrm{O}_{2}$ Levels in Blood: Comparison of Citrate and EDTA. Int. J. Pathol. Clin. Res. 2018, 4, 083. [CrossRef]

6. Mao, Y.; Zhao, Q.; Pan, T.; Shi, J.; Jiang, S.; Chen, M.; Zhou, B.; Tian, Y. Platinum porphyrin/3(trimethoxysily)propylmethacrylate functionalized flexible PDMS micropillar arrays as optical oxygen sensors. New J. Chem. 2017, 41, 5429-5435. [CrossRef]

7. Kimura, T.; Watanabe, S.; Sawada, S.-I.; Shibasaki, Y.; Oishi, Y. Preparation and optical properties of polyimide films linked with porphyrinato $\mathrm{Pd}(\mathrm{II})$ and $\mathrm{Pt}(\mathrm{II})$ complexes through a triazine ring and application toward oxygen sensors. J. Polym. Sci. Part A Polym. Chem. 2017, 55, 1086-1094. [CrossRef]

8. Önal, E.; Ay, Z.; Yel, Z.; Ertekin, K.; Gurek, A.G.; Topal, S.Z.; Hirel, C. Design of oxygen sensing nanomaterial: synthesis, encapsulation of phenylacetylide substituted $\mathrm{Pd}(\mathrm{II})$ and $\mathrm{Pt}(\mathrm{II})$ meso-tetraphenylporphyrins into poly(1-trimethylsilyl-1-propyne) nanofibers and influence of silver nanoparticles. RSC Adv. 2016, 6, 9967-9977. [CrossRef]

9. Önal, E.; Saß, S.; Hurpin, J.; Ertekin, K.; Topal, S.Z.; Kume, M.U.; Hirel, C. Lifetime-based oxygen sensing properties of palladium(II) and platinum(II) meso-tetrakis(4-phenylethynyl)phenylporphyrin. J. Fluoresc. 2017, 27, 861-868. [CrossRef]

10. Borisov, S.M. Brief Overview of the Most Common Indicators, Chapter 1: Fundamentals of Quenched Phosphorescence $\mathrm{O}_{2}$ Sensing and Rational Design of Sensor Materials, Quenched-phosphorescence Detection of Molecular Oxygen. In Applications in Life Sciences; Papovsky, D.B., Dmitriev, R.I., Eds.; Royal Society of Chemistry: Croydon, UK, 2018; pp. 7-9.

11. Buchler, J.W. The Porphyrins; Dolphin, D., Ed.; Elsevier: Amsterdam, The Netherlands, 1978; Volume 1, p. 389.

12. Mink, L.M.; Neitzel, M.L.; Bellomy, L.M.; Falvo, R.E.; Boggess, R.K.; Trainum, B.T.; Yeaman, P. Platinum(II) and platinum(IV) porphyrin complexes: synthesis, characterization, and electrochemistry. Polyhedron 1997, 16, 2809-2817. [CrossRef]

13. Paolesse, R.; Nardis, S.; Monti, D.; Stefanelli, M.; DiNatale, C. Porphyrinoids for Chemical Sensor Applications. Chem. Rev. 2017, 117, 2517-2583. [CrossRef] [PubMed]

14. Verrelli, G.; Lvova, L.; Paolesse, R.; Di Natale, C.; D'Amico, A. Metalloporphyrin-Based Electronic Tongue: an Application for the Analysis of Italian White Wines. Sensors 2007, 7, 2750-2762. [CrossRef] [PubMed]

15. Lvova, L.; Verrelli, G.; Stefanelli, M.; Nardis, S.; Di Natale, C.; D'Amico, A.; Makarychev-Mikhailov, S.; Paolesse, R. Platinum porphyrins as ionophores in polymeric membrane electrodes. Analyst 2011, 136, 4966. [CrossRef] [PubMed]

16. Creanga, I.; Palade, A.; Lascu, A.; Birdeanu, M.; Fagadar-Cosma, G.; Fagadar-Cosma, E. Manganese(III) porphyrin sensitive to $\mathrm{H}_{2} \mathrm{O}_{2}$ detection. Dig. J. Nanomater. Biostructures 2015, 1, 315-321.

17. Lascu, A.; Palade, A.; Fagadar-Cosma, G.; Creanga, I.; Ianasi, C.; Serbachievici, I.; Birdeanu, M.; Fagadar-Cosma, E. Mesoporous manganese-porphyrin-silica hybrid nanomaterial sensitive to $\mathrm{H}_{2} \mathrm{O}_{2}$ fluorescent detection. Mater. Res. Bull. 2016, 74, 325-332. [CrossRef]

18. Fagadar-Cosma, E.; Badea, V.; Fagadar-Cosma, G.; Palade, A.; Lascu, A.; Fringu, I. Trace Oxygen Sensitive Material Based on Two Porphyrin Derivatives in a Heterodimeric Complex. Molecules 2017, 22, 1787. [CrossRef]

19. Sebarchievici, I.; Tăranu, B.O.; Birdeanu, M.; Rus, S.F.; Fagadar-Cosma, E. Electrocatalytic behavior and application of manganese porphyrin/gold nanoparticle- surface modified glassy carbon electrodes. Appl. Surf. Sci. 2016, 390, 131-140. [CrossRef]

20. Fagadar-Cosma, E.; Sebarchievici, I.; Lascu, A.; Creanga, I.; Palade, A.; Birdeanu, M.; Taranu, B.; Fagadar-Cosma, G. Optical and electrochemical behavior of new nano-sized complexes based on gold-colloid and Co-porphyrin derivative in the presence of $\mathrm{H}_{2} \mathrm{O}_{2}$. J. Alloys Compd. 2016, 686, 896-904. [CrossRef]

21. Fu, J.; Li, X.; Ng, D.K.P.; Wu, C. Encapsulation of phthalocyanines in biodegradable poly(sebacic anhydride) nanoparticles. Langmuir 2002, 18, 3843-3847. [CrossRef]

22. Fagadar-Cosma, E.; Cseh, L.; Badea, V.; Fagadar-Cosma, G.; Vlascici, D. Combinatorial Synthesis and Characterization of New Asymmetric Porphyrins as Potential Photosensitizers in Photodynamic Therapy. Comb. Chem. High Throughput Screen. 2007, 10, 466-472. [CrossRef] 
23. Niu, C.-G.; Gui, X.-Q.; Zeng, G.-M.; Guan, A.-L.; Gao, P.-F.; Qin, P.-Z. Fluorescence ratiometric pH sensor prepared from covalently immobilized porphyrin and benzothioxanthene. Anal. Bioanal. Chem. 2005, 383, 349-357. [CrossRef] [PubMed]

24. Lindsey, J.S.; Hsu, H.C.; Schreiman, I.C. Synthesis of tetraphenylporphyrins under very mild conditions. Tetrahedron Lett. 1986, 27, 4969-4970. [CrossRef]

25. Sol, V.; Chaleix, V.; Granet, R.; Krausz, P. An efficient route to dimeric porphyrine RGD peptide conjugates via olefin metathesis. Tetrahedron 2008, 64, 364-371. [CrossRef]

26. Dudas, Z.; Enache, C.; Fagadar-Cosma, G.; Armeanu, I.; Fagadar-Cosma, E. Hybrid silica-porphyrin materials with tailored pore sizes. Mater. Res Bull. 2010, 45, 1150-1156. [CrossRef]

27. Yamashita, K.; Katsumata, N.; Tomita, S.; Fuwa, M.; Fujimaki, K.; Yoda, T.; Hirano, D.; Sugiura, K. Facile and practical synthesis of platinum(II) porphyrins under mild conditions. Chem. Lett. 2015, 44, $492-494$. [CrossRef]

28. Vlascici, D.; Fagadar-Cosma, G.; Plesu, N.; Lascu, A.; Petric, M.; Crisan, M.; Belean, A.; Fagadar-Cosma, E. Potentiometric sensors for iodide and bromide based on Pt(II)-porphyrin. Sensors 2018, 18, 2297. [CrossRef]

29. Lomova, T.N.; Berezin, B.D. Porphyrin complexes with $\mathrm{p}, \mathrm{d}$ and $\mathrm{f}$ metals in high oxidation states: structures, electronic absorption, and IR spectra. Russ. J. Coord. Chem. 2001, 27, 85-104. [CrossRef]

30. Liu, X.-G.; Feng, Y.-Q.; Zhao, Y.; Chen, H.-L.; Li, X.-G. Synthesis, characterization and spectroscopic investigation of azo-porphyrins. Dyes Pigment. 2007, 75, 413-419. [CrossRef]

31. Roy, D.R.; Shah, E.V.; Roy, S.M. Optical Activity of Co-Poprhyrin in the Light of IR and Raman Spectroscopy: A Critical DFT Investigation. Spectrochim. Acta Part A 2017, 190, 121-128. [CrossRef]

32. Hellwig, P.; Melin, F. Infrared Absorbance Spectra of Porphyrins and Related Compounds, Chapter 36: Recent Applications of Infrared Spectroscopy and Microscopy in Chemistry, Biology and Medicine. In Handbook of Porphyrin Science with Applications to Chemistry, Physics, Materials Science, Engineering, Biology and Medicine; Kadish, K.M., Smith, K.M., Guilard, R., Eds.; World Scientific: Singapore, 2010; Volume 7, p. 443.

33. Lian, W.; Sun, Y.; Wang, B.; Shan, N.; Shi, T. Synthesis and properties of 5,10,15,20-tetra[4-(3,5dioctoxybenzamidephenyl] porphyrin and its metal complexes. J. Serb. Chem. Soc. 2012, 77, 335-348. [CrossRef]

34. Gu, X.; Wang, H.; Schultz, Z.D.; Camden, J.P. Sensing Glucose in Urine and Serum and Hydrogen Peroxide in Living Cells by Use of a Novel Boronate Nanoprobe Based on Surface-Enhanced Raman Spectroscopy. Anal. Chem. 2016, 88, 7191-7197. [CrossRef] [PubMed]

35. Fagadar-Cosma, E.; Lascu, A.; Shova, S.; Zaltariov, M.F.; Birdeanu, M.; Croitor, L.; Balan, A.; Anghel, D.; Stamatin, S. X-Ray structure elucidation of a Pt-metalloporphyrin and its application for obtaining sensitive AuNPs-plasmonic hybrids capable to detect triiodide anions. Int. J. Mol. Sci. 2019, 20, 710. [CrossRef] [PubMed]

36. Lascu, A.; Plesu, N.; Anghel, D.; Birdeanu, M.; Vlascici, D.; Fagadar-Cosma, E. Optical detection of bromide ions using Pt(II)-5,10,15,20-tetra-(4-methoxy-phenyl)-porphyrin. Chemosensors 2019, 7, 21. [CrossRef]

37. Barona-Castaño, J.C.; Carmona-Vargas, C.C.; Brocksom, T.J.; de Oliveira, K.T. Porphyrins as Catalysts in Scalable Organic Reactions. Molecules 2016, 21, 310. [CrossRef] [PubMed]

38. Guzman, L.; Segarrab, M.; Chimenos, J.M.; Fernandez, M.A.; Espiell, F. Gold cyanidation using hydrogen peroxide. Hydrometallurgy 1999, 52, 21-35. [CrossRef]

39. Mills, A.; Tommons, C.; Bailey, R.T.; Tedford, M.C.; Crilly, P.J. Reversible, fluorescence-based optical sensor for hydrogen peroxide. Analyst 2007, 132, 566-571. [CrossRef]

40. Dhanjai; Sinha, A.; Lu, X.; Wu, L.; Tan, D.; Li, Y.; Chen, J.; Jain, R. Voltammetric sensing of biomolecules at carbon based electrode interfaces: A review. TrAC Trends Anal. Chem. 2018, 98, 174-189. [CrossRef]

41. Yang, X.; Ouyang, Y.; Wu, F.; Hu, Y.; Ji, Y.; Wu, Z. Size controllable preparation of gold nanoparticles loading on graphene sheets-cerium oxide nanocomposites modified gold electrode for nonenzymatic hydrogen peroxide detection. Sens. Actuators B 2017, 238, 40-47. [CrossRef]

42. Horozova, E.; Dodevska, T.; Dimcheva, N. Modified graphite electrodes as catalysts for electroreduction of hydrogen peroxide. Bulg. Chem. Commun. 2008, 40, 233-239.

43. Li, Z.; Zheng, X.; Zheng, J. A non-enzymatic sensor based on Au@Ag nanoparticles with good stability for sensitive detection of $\mathrm{H}_{2} \mathrm{O}_{2}$. New J. Chem. 2016, 40, 2115-2120. [CrossRef] 
44. Janasek, D.; Vastarella, W.; Spohn, U.; Teuscher, N.; Heilmann, A. Ruthenium/rhodium modified gold electrodes for the amperometric detection of hydrogen peroxide at low potentials. Anal. Bioanal. Chem. 2002, 374, 1267-1273. [CrossRef] [PubMed]

45. Mounesh; Reddy, K.R.V. Sensitive and reliable electrochemical detection of Nitrite and $\mathrm{H}_{2} \mathrm{O}_{2}$ Embellish-CoPc coupled with Appliance of composite MWCNTs. Anal. Chim. Acta 2020, 1108, 98-107. [CrossRef]

46. Su, G.; Wei, Y.; Guo, M. Direct Colorimetric Detection of Hydrogen Peroxide Using 4-Nitrophenyl Boronic Acid or Its Pinacol Ester. Am. J. Anal. Chem. 2011, 2, 879-884. [CrossRef]

47. Nikolaev, K.G.; Ermolenko, Y.E.; Offenhäusser, A.; Ermakov, S.S.; Mourzina, Y.G. Multisensor Systems by Electrochemical Nanowire Assembly for the Analysis of Aqueous Solutions. Front. Chem. 2018, 6, 256. [CrossRef] [PubMed]

48. Wen, F.; Dong, Y.; Feng, L.; Wang, S.; Zhang, S.; Zhang, X. Horseradish Peroxidase Functionalized Fluorescent Gold Nanoclusters for Hydrogen Peroxide Sensing. Anal. Chem. 2011, 83, 1193-1196. [CrossRef]

49. Zheng, H.; Su, R.; Gao, Z.; Qi, W.; Huang, R.; Wang, L.; Hea, Z. Magnetic-fluorescent nanocomposites as reusable fluorescence probes for sensitive detection of hydrogen peroxide and glucose. Anal. Methods 2014, 6, 6352-6357. [CrossRef]

50. Burmistrova, N.A.; Kolontaeva, O.A.; Duerkop, A. New Nanomaterials and Luminescent Optical Sensors for Detection of Hydrogen Peroxide. Chemosensors 2015, 3, 253-273. [CrossRef]

51. Wu, H.; Fan, S.; Jin, X.; Zhang, H.; Chen, H.; Dai, Z.; Zou, X. Construction of a Zinc Porphyrin-Fullerene-Derivative Based Nonenzymatic Electrochemical Sensor for Sensitive Sensing of Hydrogen Peroxide and Nitrite. Anal. Chem. 2014, 86, 6285-6290. [CrossRef]

(C) 2020 by the authors. Licensee MDPI, Basel, Switzerland. This article is an open access article distributed under the terms and conditions of the Creative Commons Attribution (CC BY) license (http://creativecommons.org/licenses/by/4.0/). 